\title{
P300 EVENT RELATED POTENTIAL APPLICATION TO COGNITIVE STATUS ASSESSMENT OF THE PATIENTS WITH SUBCLINICAL HYPOTHYROIDISM
}

\section{AUTHORS}

Dejanović M. ${ }^{1}$, Ivetić V. ${ }^{2}$, Nestorović V. ${ }^{1}$, Milanović Z. ${ }^{1}$, Biševac B. ${ }^{1}$, Miletić M. ${ }^{1}$, Mirić M. ${ }^{1}$

${ }^{1}$ Department of Physiology, Faculty of Medicine, University of Priština, Kosovska Mitrovica, Serbia

2 Department of Physiology, Faculty of Medicine, University of Novi Sad, Novi Sad, Serbia
CORRESPONDENT

MIRJANA DEJANOVIĆ

Medicinski fakultet, Univerzitet $u$

Prištini, Kosovska Mitrovica, Srbija

mirjana.dejanovic@gmail.com

\section{SUMMARY}

Disturbances of thyroid function are often accompanied by cognitive and affective disorders. Assessment of cognitive status in the patients with subclinical hypothyroidism represents a possibility for early diagnostics of cognitive impairment and timely introduction of necessary pharmacotherapy treatment. The aim of this study was to quantify whether there are P3 event related potential (ERP) deviations as electrophysiological markers of cognitive activity in patients with subclinical hypothyroidism. P300 potentials were examined in thirty patients with subclinical hypothyroidism and in 30 healthy subjects of the control group. P300 was recorded using the classic auditory oddball paradigm, with $20 \%$ of target and $80 \%$ of non-target stimuli. The results analysis showed a significantly longer latency P300 and reduced amplitude P300 in subjects with subclinical hypothyroidism compared to euthyroid subjects. There is also a statistically significant negative correlation between the results of a mini mental state examination and the P300 latency at Fz electrode $(r=-0.47, p<0.01)$ and $C z$ electrode $(r=-0.43, p=0.017)$. P300 ERP is important in the evaluation of patients with subclinical hypothyroidism, due to the sensitivity in the detection cognitive disorders.

Key words: P300, hypothyroidism

\section{INTRODUCTION}

It is known that thyroid hormones are important for normal brain function [1,2]. Disturbances of thyroid function are often accompanied by cognitive and affective disorders. Of particular importance is the diagnosis of cognitive disorders, which are, however, often overlooked, and closely connected with the quality of life of patients. Clinically manifest hypothyroidism can lead to changes in many cognitive domains, including attention, concentration, memory, executive function, and impact of subclinical hypothyroidism on cognitive function is still unclear [3]. Subclinical hypothyroidism may have similar, but more subtle effects on cognitive functions.

Subclinical hypothyroidism, defined as an asymptomatic state with elevated serum thyroid stimulating hormone (TSH) levels while the values of free and total tyroxin (T4) are normal [4]. There is no consensus in the literature whether the subclinical hypothyroidism may induce change of the cognitive functions. Some authors argue that the mild subclinical hypothyroidism (average TSH concentration less than $10 \mathrm{mU} / \mathrm{L}$ ) may induce cognitive and affective disorders which can be corrected by the tyroxin substitution [5]. There are increasingly more evidence of a disturbance of cognitive function under subclinical hypothyroidism. Many authors believe that the decline in cognitive function may vary depending on the concentration of thyroxine.
Volpato followed the values of thyroxine and TSH in women with normal thyroid function for a period of three years and found that cognitive decline was faster among women with lower concentrations of thyroxine, although all were within the normal range [6]. Samuels et al. find weaker health status, cognitive dysfunction, impaired working memory, and motor learning in patients treated with thyroxine compared to 20 euthyroid persons aged 20-45 years, with TSH within the reference values [7]. Testing of thyroid function is an integral part of the diagnostic protocol for dementia [8]. On the other hand, some studies did not find a link between subclinical hypothyroidism and cognitive and affective disorders [9, 10]. There is not enough evidence that treating hypothyroidism recovers cognitive functions $[11,12,13]$.

In clinical practice, for assessing and monitoring cognitive deficits, neuropsychological tests are usually used. However, the tests require the cooperation of patients and are often very complicated and exhausting. For these reasons, special interest piqued to learn that the recently introduced new neurophysiological methods in the study of cognitive processes in healthy subjects and in clinical practice- event-related potentials as an objective neurophysiological methods can contribute to the early diagnosis of cognitive impairment. In the last 20 years P3 cognitive potentials research is very intense and clearly indicate that this component can serve as an indicator of cognitive function. In this regard, it is quite 
logical application of P300 event related potentials in patients with impaired function of the thyroid gland in the early detection and evaluation of cognitive dysfunction.

\section{THE AIM}

The aim of our study was to determine whether there are differences in the P3 potential as an electrophysiological marker of cognitive function in subclinical hypothyroidism compared to euthyroid subjects.

\section{MATERIAL AND METHODS}

The study included 30 patients (11 men and 19 women, mean age 50.1 \pm 5.2 years, range $40-62$ years), with subclinical hypothyroidism (normal mean value of FT4, mean value of TSH is 8,8 ). Patients with history of any other neurologic disease, history of traumatic brain injury, aphasia, defects in hearing, communication disorders, previous depression or other psychiatric illnesses as well as alcoholism and/or administration of medications known to influence cognitive functions were excluded. The control group consisted of 30 age and sex matched healthy volunteers ( 12 men and 18 women, mean age $51.2 \pm 6.3$ years, range $42-62$ years). All tests were conducted in the neurophysiology laboratory of the Department of Physiology, Faculty of Medicine in Novi Sad, in the morning hours and the patients came rested. Before the experiment for each patient we conducted an approximate assessment of the state of hearing and neuropsychological assessment of cognitive status using the Mini Mental State Examination (MMSE) [14]. This scale is widely accepted as a simple and relatively reliable clinical assessment instrument. Before the experiment all subjects were given the full information about the trial and were requested for the participation approval.

\section{ERP measurement}

Bioelectrical activity of the brain was recorded using $\mathrm{Ag} / \mathrm{AgCl}$ electrodes fastened on the scalp of the subject with the colodium. Two active electrodes were positioned at the central line of the scalp frontally $(\mathrm{Fz})$ and centrally $(\mathrm{Cz})$ according to the international $10-20$ system. Reference electrodes were placed at the mastoids while the ground electrode was positioned at the subject forearm. Impedance of all electrodes in all recordings was under $5 \mathrm{k} \Omega$.

P300 ERPs were recorded using the classic auditory oddball paradigm [15], with $20 \%$ of target and $80 \%$ of non-target stimuli. As the stimuli used were pure tones height of 1000 and $2000 \mathrm{~Hz}$, the strength of $90 \mathrm{~dB}$. Tones were presented to the subject trough binaural phones. The subjects were instructed to react as fast as possible to the target tones $(2000 \mathrm{~Hz})$ by pressing the button on the special handle they were holding in their preferred hand, and at the same time to ignore rhythmical nontarget tones $(1000 \mathrm{~Hz})$. The subjects were sitting on the chair in the comfortable position in the silent darkened room with their eyes open.

A 1000 ms of the cortical electrical activity was recorded after each stimulus appearance. The signal was averaged during the recording. The cortical activity signal averaging was done separately for target and non- target stimuli. At the end of the recordings P300 latency was identified as the largest positive peak at range 250$450 \mathrm{~ms}$ occurring for each electrode, in particular. Additionally, the reaction time (RT) was registered for each patient.

\section{Statistical analysis}

The statistical analyses were carried out using the Wilcoxon rank-sum test (Mann-Whitney) to compare the P300 amplitudes and latencies of the patients with those of the control subjects. Pearson's correlation coefficients were used to correlate the amplitudes and latencies of the P300 with the scores of the MMSE scale. In the interpretation of data, probability values of $p<0.05$ (two tailed) were considered statistically significant. The statistical analysis was performed, using $\mathrm{R}$ version 3.1.0 [16].

\section{RESULTS}

The results analysis showed that the average $\mathrm{P} 3 \mathrm{la}$ tency in $\mathrm{SH}$ patients was significantly longer (Fz$373 \pm 25.1 \mathrm{~ms}, \mathrm{Cz}-377 \pm 24.7$, mean \pm S.D.) than in control subjects (Fz- 349 $\pm 31.4 \mathrm{~ms}, \mathrm{Cz}-348 \pm 31.2 ; \mathrm{p}<0.01$ ). P300 latencies were statistically significantly longer in both observed brain areas (fig. 1).

The values of the amplitudes were lower in the group of $\mathrm{SH}$ patients on both electrodes $(\mathrm{Fz}-6.7 \pm 3 \mu \mathrm{V}, \mathrm{Cz}-$ $6.5 \pm 2.8 \mu \mathrm{V} ;$ mean \pm S.D) than in control subjects (Fz$10 \pm 3 \mu \mathrm{V}, \mathrm{Cz}-9 \pm 3 \mu \mathrm{V} ;$ mean \pm S.D) (fig.2). In both subject groups, the amplitudes P300 on Fz electrode were larger.

The reaction time in the group of patients was larger in comparison to the group of healthy subjects but that difference is not statistically significant. Considering the success rate and the number of errors in both groups, the group with $\mathrm{SH}$ patients has more errors but the difference was not statistically significant.

It is interesting to note the relationship between latency and amplitude of P300 and neurophysiological test for assessment of general cognitive capabilities (e.g. MMSE). The results show a statistically significant negative correlation between the results of a mini mental state examination and the P300 latency at Fz electrode $(r=-0.47, p<0.01)$ and $C z$ electrode $(r=-0.43, p=0.017)$ (fig. 3).

On the other hand, there was no correlation when the results of the MMSE were compared to the amplitude of the P300 at Fz and Cz electrode (fig.4).

\section{DISCUSION}

The numerous clinical P300 studies [17-23], strongly suggest that this ERP component, elicited by auditory, visual, olfactory or somatosensory stimuli, may be clinically useful as an index of cognitive function. Some studies show a significant correlation between weaker results on the scale of general cognitive abilities and prolonged P3 latencies. These characteristics qualify P3 component as a possible diagnostics method for cognitive status assessment. P3 ERP is particularly important in patients with weak cognitive changes regardless of its etiology which can not be proved during the clinical examination. 

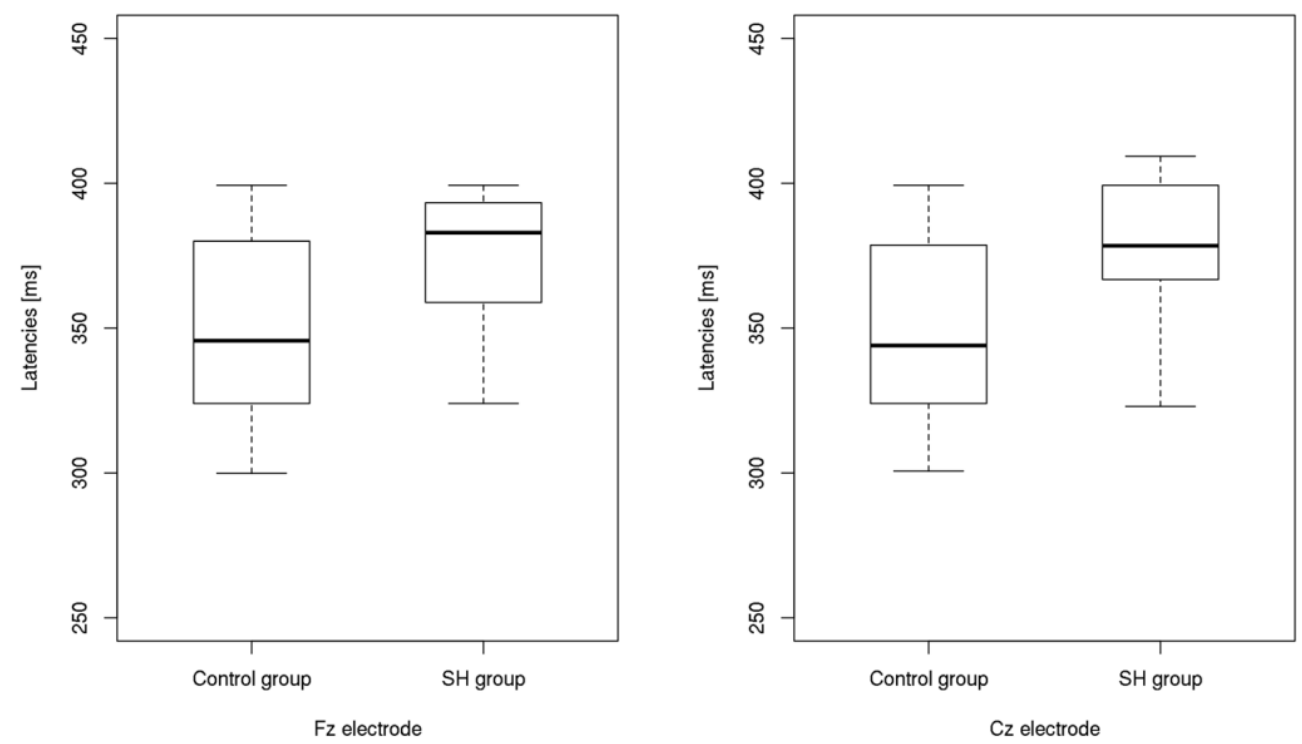

Figure 1. P300 latencies of the control group and group with subclinical hypothyroidism (SH) at Fz and Cz electrode
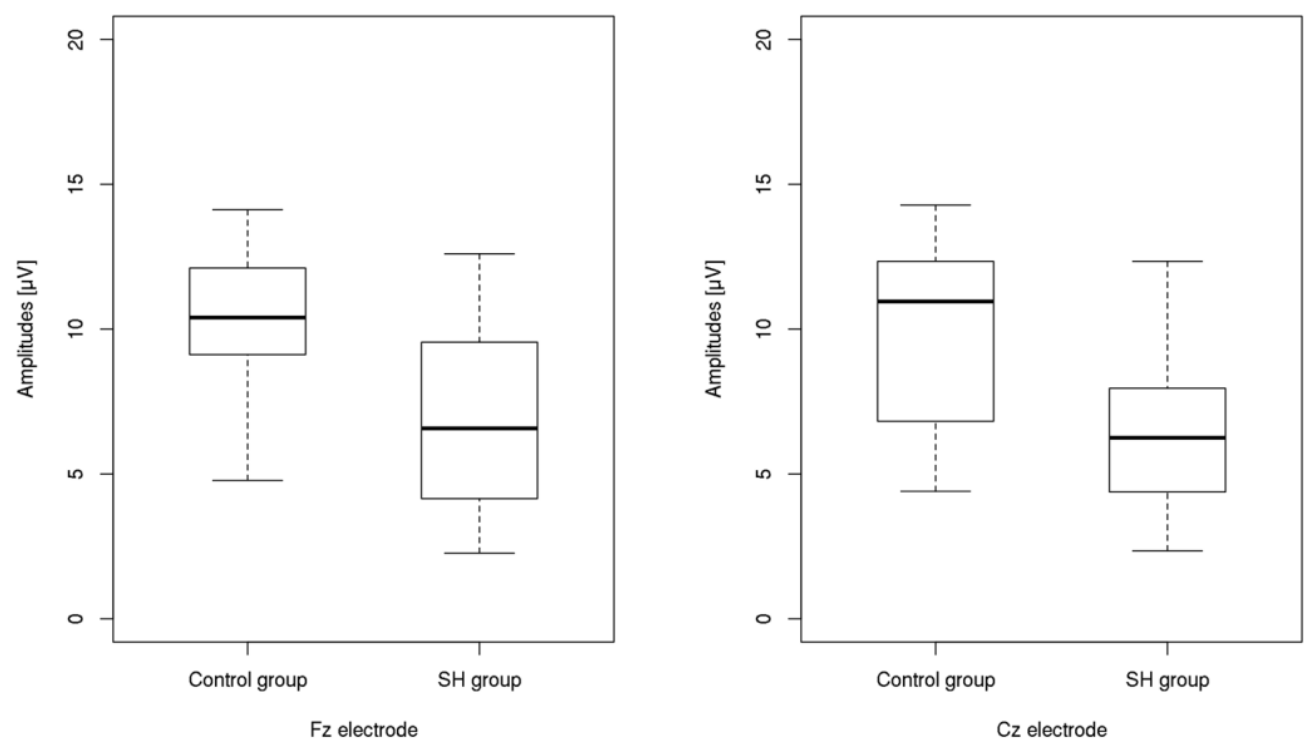

Figure 2. P300 amplitudes of the control group and group with subclinical hypothyroidism (SH) at Fz and Cz electrode

We have used P3 ERP component for the assesment of cognitive abilities in patients with subclinical hypothyroidism. By our knowledge there is just a few published works researching the possibility of using P3 ERP in the assessment of cognitive status in hypotiroidism. Jensovsky et al. used latency of P3 cognitive potentials in the evaluation of the impact of thyroxine therapy on the cognitive function [24]. They showed significantly prolonged P3 latency before levothyroxine treatment when the mean concentration of TSH was $7.1 \mathrm{mU} / \mathrm{L}$. After the treatment, with the normalization of TSH, the values of P3 components are normalized also.

Munte et al. analyzed cognitive evoked potentials and neuropsychological tests in patients operated from thyroid cancer, first while being euthyroid and then during hypothyroidism over one month period without thy- roxine in which they had been prepared for scintigraphy with iodine [25]. These authors used visual stimulation to elicit P3 components and founded prolonged latency and reduced P3 amplitude during hypothyroidism, which lasted only a month but was exceptional (total T4 mean $17.3 \mathrm{nmol} / \mathrm{l}$, TSH mean $86.3 \mathrm{mU} / \mathrm{l}$ ).

In our study, comparison of parameters P3 component showed a significantly longer latency and reduced amplitude in subjects with subclinical hypothyroidism compared to euthyroid subjects. There was no difference between the groups regarding other neurophysiological indicator of brain functions such as the reaction time. Analyzing the values of P3 latency and amplitude in the control group, we find that they do not differ significantly compared to the values obtained in most other studies. Latencies in our patients amounted $373 \mathrm{~ms}$ for 

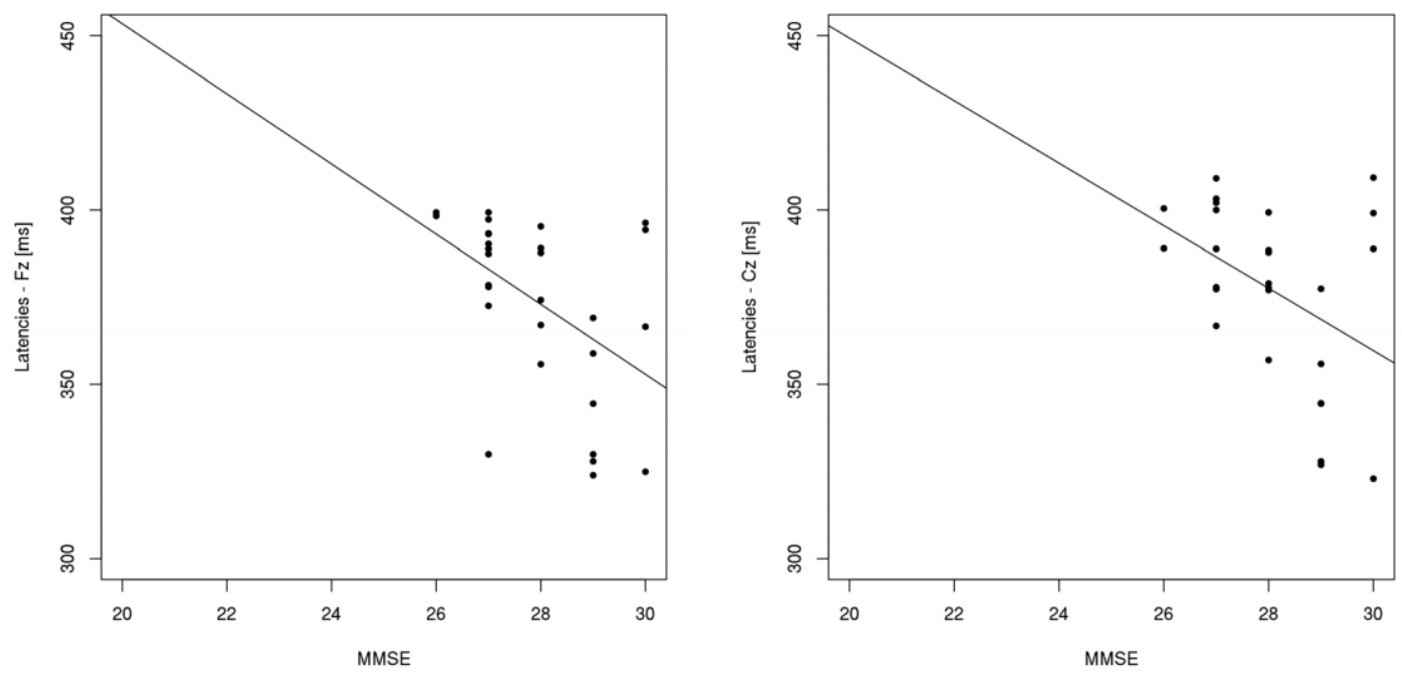

Figure 3. The correlation between the P300 latency at Fz and $\mathrm{Cz}$ electrode and the mini-mental state examination (MMSE) score
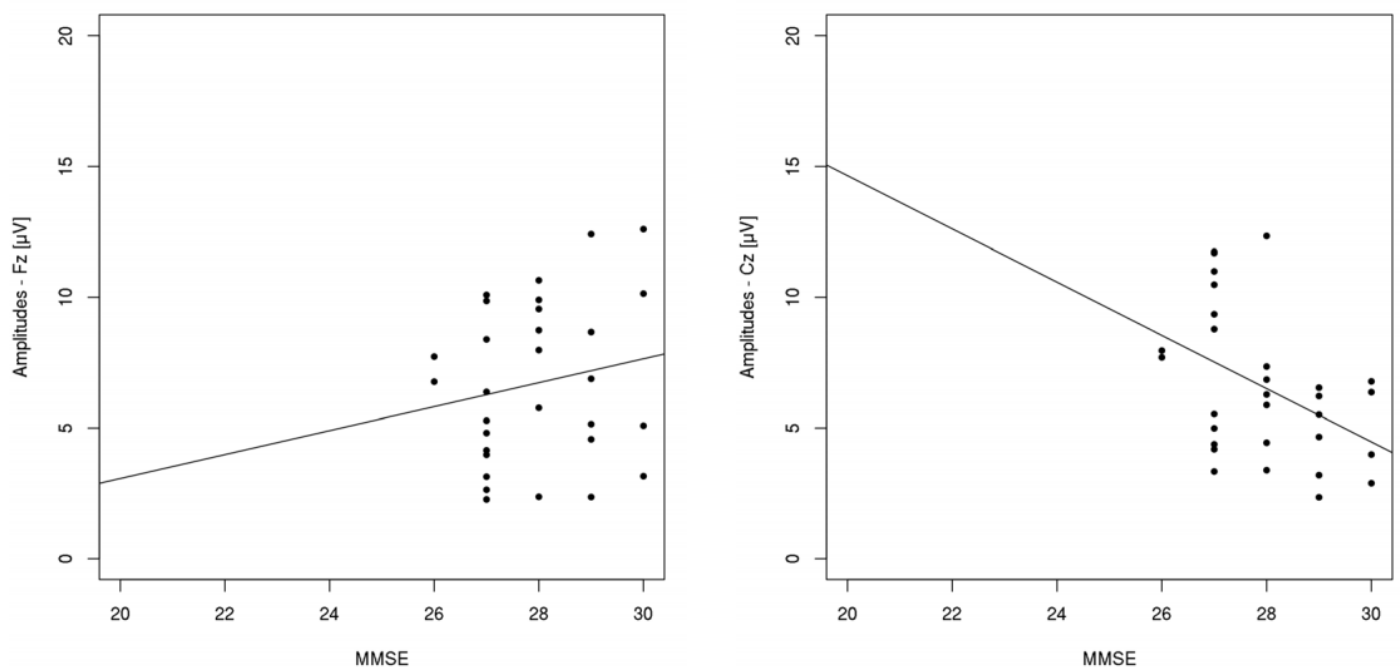

Figure 4. The correlation between the P300 amplitude at Fz and Cz electrode and the mini-mental state examination (MMSE) score

the $\mathrm{Fz}$, and $377 \mathrm{~ms}$ for the $\mathrm{Cz}$ which is consistent with the statements of other authors [26].

Considering the latency of the P3a potentials (frontally localized) the most frequently quoted value is 220 $280 \mathrm{~ms}$, and for the P3b potentials (centroparietally localized) is $310-380 \mathrm{~ms}$ [27]. Parameters of the P3 potential primarily reflect basic cognitive domains such as attention and memory. P3 amplitude waves in our study have a higher variation which is consistent with other published studies and their importance is usually in the individual monitoring or comparing different groups of respondents [28].

The subjects with subclinical hypothyroidism show a lower speed of stimulus classification, less attention capacity and slower attention redirection which is correlated with prolonged P300 latency. Attention redirection speed correlated negatively with values of the MMSE. On the other hand, the capacity of attention, which is reflected in the amplitude of P3 were reduced by hypothyroidism but there is no correlation with the test for assessing general cognitive ability (MMSE). The importance of prolonged latency of the P3 component is more sensitive in identifying small changes in working memory which may be found in hypothyroidism [29]. Determination of the event related potentials can be a useful tool in routine clinical practice as an additional diagnostic tool.

However, reaction time shows its shortcomings in the identification of subtle cognitive changes, since the reaction time reflects only a summary of all phases of cognitive processes, such as the perception of stimuli, discrimination, evaluation, selection and execution of appropriate response.

\section{CONCLUSION}

Our study emphasizes the importance of P300 ERP in the evaluation of patients with subclinical hypothyroidism, due to the sensitivity in the detection of specific and subtle cognitive disorders. 
Patients with subclinical hypothyroidism had significantly longer P3 latency and reduced P3 amplitude as compared to healthy individuals which gives evidence for impaired cognitive functions in SH patients. Latency of P300 potentials stands out as a very good indicator of cognitive decline in subclinical hypothyroidism

\section{REFERENCES}

1. Davis JD, Tremont G. Neuropsychiatric aspects of hypothyroidism and treatment reversibility. Minerva Endocrinologica. 2007; 32: 49-65.

2. Bernal J. Action of thyroid hormone in brain. Journal of Endocrinological Investigation. 2002; 25: 268-288.

3. Owen PJ, Lazarus JH. Subclinical hypothyroidism:the case for treatment. Trends Endocrinol Metab. 2003; 14: 257-261.

4. Monzani F, Dardano A, Caraccio N. Does treating subclinical hypothyroidism improve markers of cardiovascular risk? Treat Endocrinol. 2006; 5: 65-81

5. Gharib H, Tuttle M.R, Baskin J.H, Fish L.H, Singer P.A, Mcdermott M.T. Subclinical thyroid dysfunction: A joint statement on management from the American Association of Clinical Endocrinologists the American Thyroid Association, and the Endocrine Society. J Clin Endocrinol Metab. 2005; 90(1): 581-5; discussion 586-7

6. Volpato S, Guralnik JM, Fried LP, Remaley AT, Cappola AR, Launer LJ. Serum thyroxine level and cognitive decline in euthyroid older women. Neurology 2002; 58(7):1055-1061.

7. Samuels MH, Schuff KG, Carlson NE, Carello P, Anowsky JS. Health status, psychological symptoms, mood, and cognition in lthyroxine-treated hypothyroid subjects. Thyroid. 2007; 17: 249-258.

8. Bird T. D, Miller B.L. Alzheimer's disease and other dementias. In: Kasper D. L, Braunwald E, Hauser S. L, Longo D. L, Jameson L. J, eds. Harrison's Principles of Internal Medicine. 16 edn. New York. McGraw-Hill. 2005; 2397.

9. Jorde R, Waterloo K, Storhaug H, Nyrnes A, Sundsfjord J, Jenssen TG. Neuropsychological function and symptoms in subjects with subclinical hypothyroidism and the effect of thyroxine treatment. J Clin Endocrinol Metab. 2006; 91(1):145-153.

10. Roberts $L M$, Pattison $\mathrm{H}$, Roalfe A et al. Is subclinical thyroid dysfunction in the elderly associated with depression or cognitive dysfunction? Ann Intern Med. 2006; 145(8):573-581

11. Surks MI, Ortiz E, Daniels GH, Sawin CT, Col NF, Cobin RH, Franklyn JA, Hershman JM, Burman KD, Denke MA, Gorman C, Cooper RS, Weissman NJ. Subclinical thyroid disease: scientific review and guidelines for diagnosis and management. JAMA . 2004; 291:228-238.

12. Helfand M. Screening for subclinical thyroid dysfunction in nonpregnant adults: a summary of the evidence for the U.S. Preventive Services Task Force. Ann Int Med. 2004; 140: 128-141

13. Wekking $E M$, Appelhof $B C$, Fliers $E$ et al. Cognitive functioning and well-being in euthyroid patients on thyroxine replacement therapy for primary hypothyroidism. Eur J Endocrinol 2005; 153(6):747-753.

14. Folstein MF, Folstein SE, MCHugh PR."Mini-mental state". A practical method for grading the cognitive state of patients for the clinician, J Psychiatr Res. 1975 Nov; 12(3):189-98.

15. Polich J, Herbst KL. P300 as a clinical assay: rationale, evaluation, and findings. Int J Psychophysiol. 2000; 38: 3-19.

16. R Core Team R: A language and environment for statistical computing. R Foundation for Statistical Computing, Vienna, Austria. 2014. URL http://www.R-project.org/

17. Yamaguchi S, Knight RT. P300 generation by novel somatosensory stimuli. Electroencephalogr Clin Neurophysiol. 1991; 78: 5055.

18. Bennys K, Portet F, Touchon J, Rondouin G. Diagnostic value of event-related evoked potentials N200 and P300 subcomponents in early diagnosis of Alzheimer's disease and mild cognitive impairment. J Clin Neurophysiol. 2007, 24: 405-412.

19. Golob EJ, Irimajiri R, Starr A. Auditory cortical activity in amnestic mild cognitive impairment: relationship to subtype and conversion to dementia. Brain 2007; 130: 740-752.

20. Frodl T, Hampel H, Juckel G, Bürger K, Padberg F, Engel RR, Möller HJ, Hegerl U. Value of event-related P300 subcomponents in the clinical diagnosis of mild cognitive impairment and Alzheimer's Disease. Psychophysiology 2002; 39: 75-181.

21. Golob EJ, Johnson JK, Starr A. Auditory event-related potentials during target detection are abnormal in mild cognitive impairment. Clin Neurophysiol 2002; 113: 151-161.

22. Irimajiri R, Golob EJ, Starr A. Auditory brain-stem, middle- and long-latency evoked potentials in mild cognitive impairment. Clin Neurophysiol. 2005; 116: 1918-1929.

23. Polich J. P300 in clinical applications. In Electroencephalography: basic principles, clinical applications and related fields. Edited by Niedermayer E, Lopes de la Silva, Urban F. Schwartzenberger, Baltimore-Munich. 1999; 1073-1091.

24. Jensovsky J, Ruzicka E, Spackova N, Hejdukova B. Changes of event related potentials and cognitive processes in patients with subclinical hypotiroidism after thyroxine treatment. Endocrine Regulations. 2002; 36: 122-155. 
25. Munte TF, Lill C, Otting G, Brabant G. Cognitive changes in short-term hypothyroidism assessed with event-related brain potentials. Psychoneuroendocrinology. 2004; 29(9):1109-1118.

26. Hansenne $M$. The $\mathrm{p} 300$ cognitive event-related potential. II. Individual variability and clinical application in psychopathology. Neurophysiol Clin. 2000; 30: 211-231.

27. Bocquillon P, Dujardin K, Betrouni N, Phalempin V, Houdayer E, Bourriez JL, Derambure P, Szurhaj W. Attention impairment in temporal lobe epilepsy: a neurophysiological approach via analysis of the P300 wave. Hum Brain Mapp. 2009; 30(7):2267-77.

28. Chiappa KH: Principles of evoked potentials. In: Chiappa KH, ed. Evoked potencials in clinical medicine. Raven Press. 1990; New York, 1-36. Ed. 2

29. Zhu DF, Wang ZX, Zhang DR, Pan ZL, He S, Hu XP, Chen XC \& Zhou JN, fMRI revealed neural substrate for reversible working memory dysfunction in subclinical hypothyroidism. Brain. 2006; 129: 2923-2930.

\section{SRPSKI}

\section{PRIMENA P300 KOGNITIVNO EVOCIRANOG POTENCIJALA ZA PROCENUKOGNITIVNOG STATUSA KOD SUBKLINIČKE HIPOTIREOZE}

Dejanović M. ${ }^{1}$, Ivetić $\mathrm{V} .{ }^{2}$, Nestorović V. ${ }^{1}$, Milanović $Z{ }^{1}{ }^{1}$, Biševac B. ${ }^{1}$, Miletić M. ${ }^{1}$, Mirić $M .{ }^{1}$

${ }^{1}$ Institut za Fiziologiju, Medicinski fakultet, Priština, Kosovska Mitrovica, Srbija

${ }^{2}$ Zavod za Fiziologiju, Medicinski fakultet, Novi Sad, Srbija

\section{SAŽETAK}

Oboljenja štitaste žlezde su često praćena kognitivnim i afektivnim poremećajima. Procena kognitivnog statusa kod bolesnika sa subkliničkom hipotireozom predstavlja mogućnost za ranu dijagnostiku kognitivnog oštećenja i blagovremeno uvođenje farmakološke terapije. Cilj ovog istraživanja bio je da utvrdimo da li postoje promene P3 latence i amplitude kao elektrofizioloških markera kognitivne aktivnosti kod pacijenata sa subkliničkom hipotireozom u odnosu na eutiroidne subjekte. $U$ ispitivanje je uključeno trideset pacijenata sa subkliničkom hipotireozom i 30 zdravih ipitanika u kontrolnoj grupi. Za izazivanje P3 potencijala koristili smo klasičnu oddball paradigmu sa $20 \%$ ciljnih i $80 \%$ neciljnih stimulusa. Rezultati su pokazali produžene P300 latence i smanjene P300 amplitude kod osoba sa subkliničkom hipotireozom u odnosu na eutireoidne subjekte. Takođe postoji statistički značajna negativna korelacija između rezultata male skale za procenu mentalnog statusa i P300 latenci na Fz elektrodi $(r=-0.47, p<0,01)$ i Cz elektrodi $(r=-0.43$, p $=0.017$ ). P300 kognitivni potencijal je važan u evaluaciji pacijenata sa subkliničkom hipotireozom zbog osetljivosti u otkrivanju kognitivnih poremećaja.

Ključne reči: $\mathrm{P} 300$, hipotiroidizam 